EPJ Web of Conferences 54, 01003 (2013)

DOI: $10.1051 /$ epjconf/20135401003

C) Owned by the authors, published by EDP Sciences - SIF, 2013

\title{
Future requirements for fossil power plants
}

\author{
M. Gaderer and H. Spliethoff \\ Institute of Energy Systems, Technische Universität München - München, Germany
}

\begin{abstract}
Summary. - The fast increasing installation of technologies to convert renewable energy into power influences the operation of conventional power plants. New requirements on the technology, on the operation and on the economic have to be considered for already running and future power plants. Currently, first experiences with such a production and market situation are available. Technologies are discussed to store power and to reduce $\mathrm{CO}_{2}$ emissions. New compensation models are necessary to enable economic operation of fossil power plants in base load. This article gives a short review about available technologies and future challenges.
\end{abstract}

\section{1. - Energy market}

Over the last 20 years, the worldwide primary energy demand has been increasing by $2 \%$ per year and in 2008 it ranged at approximately 514 Exajoule (142.000 TWh). Whereas in Europe the increase per annum amounts to $0.7 \%$, the main consumers being countries in Asia, like China, with an average increase of energy demand of $7.6 \%$ per year over the same time. Different statistics and scenarios exist on how to cover the energy demand.

The scenario in fig. 1 is based on the actual energy mix and ends in 2030 with a demand of $80 \%$ based on coal, oil and natural gas, with only $14 \%$ being covered by renewables and $6 \%$ produced by nuclear energy (see fig. 1 ). 


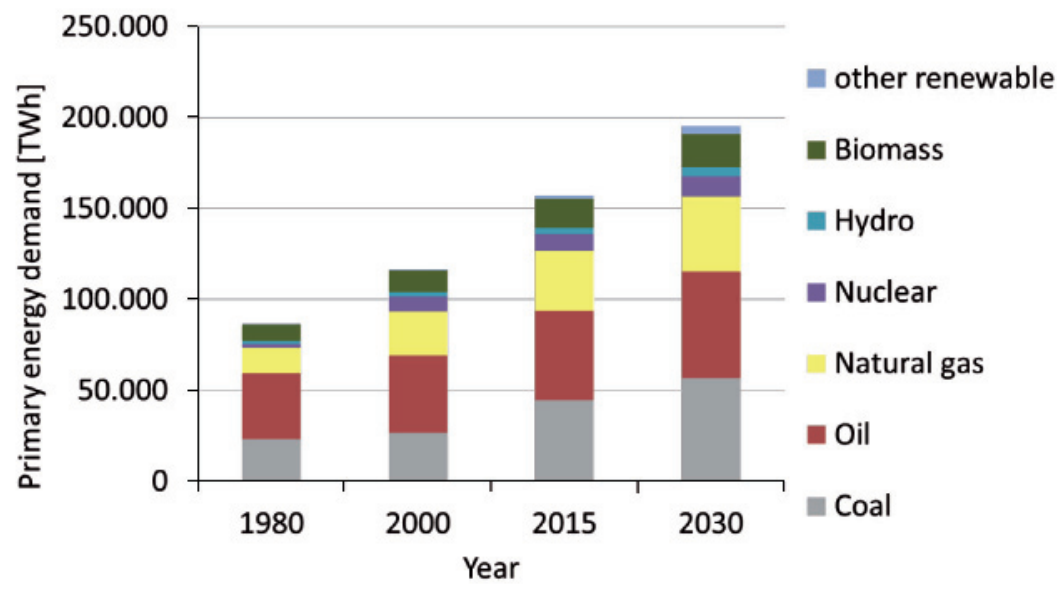

Fig. 1. - Worldwide primary energy demand [1].

Apparently, fossil energy carriers will still play a very important role in the future. For some areas,coal is of importance due to the local availability. Actually, China covers $66 \%$ of the demand with coal, USA $24 \%$ and Europe $19 \%$. Biomass is used for $6-10 \%$ of the primary energy demand, thus ranging between 30 and $70 \%$ of the realistic potential, which, obviously, differs considerably depending on the individual countries.

In 2030 , renewables will contribute $22 \%$ to power production, $67 \%$ will be covered by fossils and $10 \%$ by nuclear power, this distribution being comparable to the actual situation (see fig. 2).

The application of renewables differs considerably depending on the local situation.

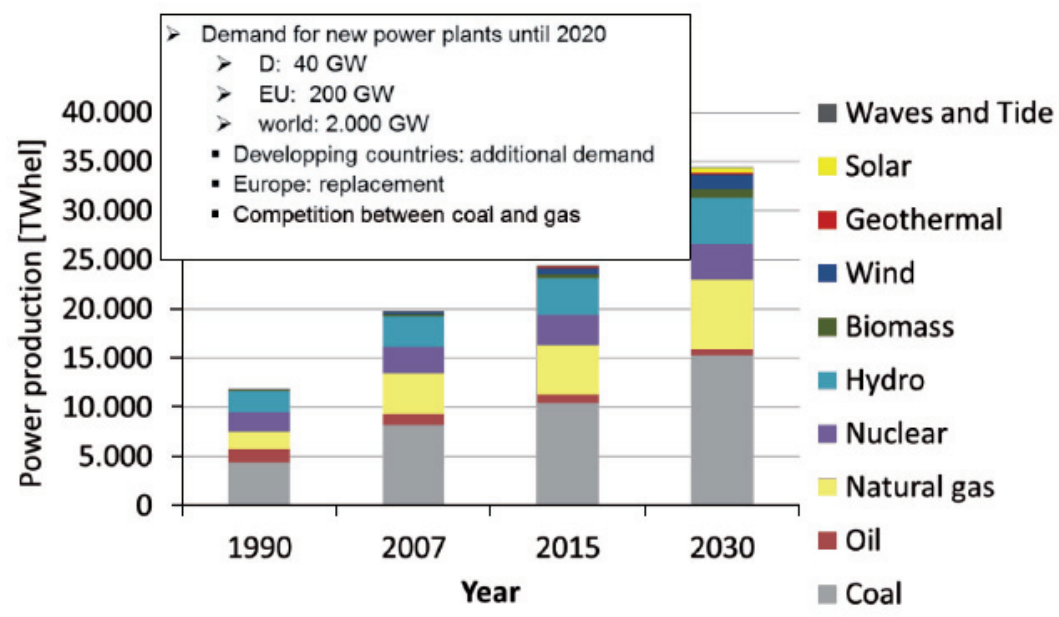

Fig. 2. - Worldwide power production [1]. 

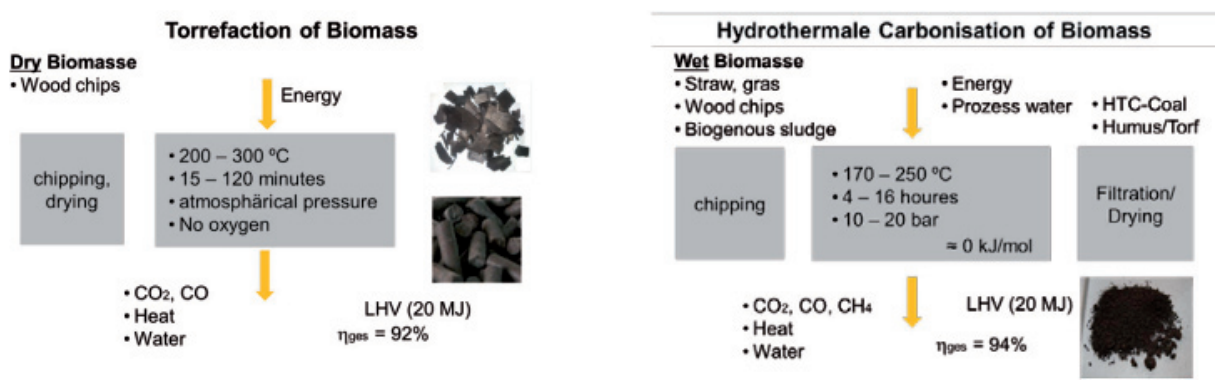

Fig. 3. - Torrefaction and hydrothermal carbonization as pretreatment technology for biomass.

\section{Biomass}

Countries in Northern Europe, Canada and Russia dispose of a high potential of biomass resources mainly based on wooden biomass whereas the major potential for countries in Europe, Asia and South America lies in agricultural biomass, which, however, causes competition with areas required for agriculture-based food. Furthermore, environmental problems originate from the change of natural areas to agricultural areas as well as the requirement of water and fertilizer for cultivation.

Although biomass is a form of stored solar energy, it is a limited resource. Compared to other renewables, it is used more flexibly for conversion into heat, power or synthetic fuels. The cost of biomass is a main economic factor and, due its extensive use, it has strongly increased in Europe since 2008, a fact that will finally limit its potential. Consequently, only cheap biogenic residuals like very wet biomass, sewage sludge or agriculture residuals as well biomass from countries like Canada or Sweden are of interest in Europe for industrial applications and for power production by co-firing of biomass in coal power stations. For this purpose, the biomass can be "upgraded" by carbonization of the biomass (fig. 3).

Torrefaction and hydrothermal carbonization are two processes, which are presently being developed to increase the volumetric energy density (fig. 4) for transport and to reduce the energy demand to mill the biomass into fine particles (size of $<1 \mathrm{~mm}$ ) like coal for combustion in a dust burner.

\begin{tabular}{|l|c|c|c|c|}
\hline & $\begin{array}{c}\text { Wood } \\
\text { chips }\end{array}$ & $\begin{array}{c}\text { Wood- } \\
\text { pellets }\end{array}$ & $\begin{array}{c}\text { HTC/Torr. } \\
\text { Biomass }\end{array}$ & $\begin{array}{c}\text { HTC/Torr. } \\
\text { Pellets }\end{array}$ \\
\hline Water content (\%) & 35 & 10 & 5 & 5 \\
\hline LHV (MJ/kgtr) & 17,7 & 17,7 & 20,4 & 20,4 \\
\hline Bulk density $\left(\mathrm{kg} / \mathrm{m}^{3}\right)$ & 475 & 650 & 230 & 750 \\
\hline $\begin{array}{l}\text { Energy density } \\
\left(\mathrm{GJ} / \mathrm{m}^{3}\right)\end{array}$ & 5 & 10,1 & 4,7 & 15 \\
\hline Ash content $(\%)$ & 3 & 1 & 5 & 5 \\
\hline
\end{tabular}

Fig. 4. - Comparison of the properties of different biomass [2]. 

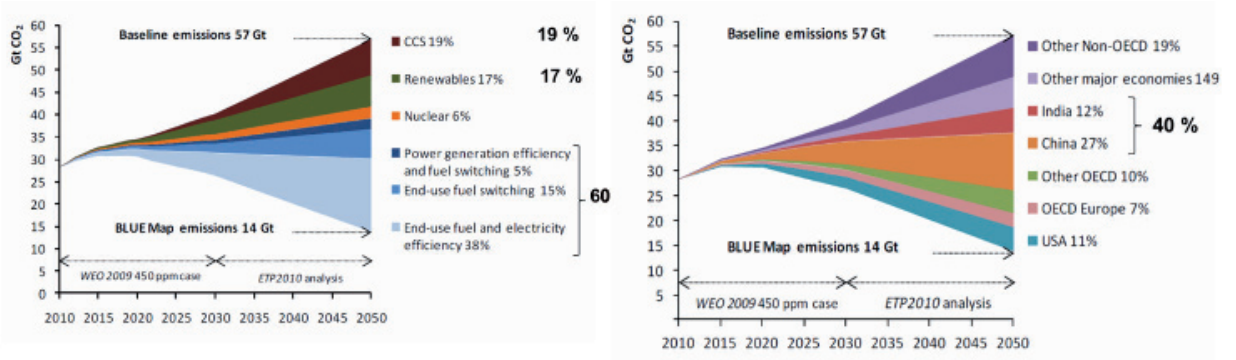

Fig. 5. - Left: scenario to reduce $\mathrm{CO}_{2}$ emissions worldwide. Right: amount in relation to countries [3].

\section{Solar, wind and hydro}

Compared to biomass, wind and solar energy are free of charge, but the availability cannot be controlled and the storage of energy, e.g. hydro pump storages, is limited. However, the technology could be standardized(on shore wind and photovoltaic-PV) and manufactured in serial production which would allow the installation of a high number of units worldwide within a short period of time with limited risk, thus considerably reducing the production costs (see photovoltaic). This is a major advantage of solar and wind technology compared to others like biomass power plants or solar thermal power plants. Wind and solar power plants (actually mainly photovoltaic) will therefore be the major technology for new power plants based on renewables.

However,the market for renewables is difficult and still strongly influenced by public subsidies. Technologies requiring high investment costs like solar thermal power and off-shore wind are difficult to realize.

Hydropower is still being used; however, the implementation of new plants is extremely time-consuming and cost-intensive. Of special interests are hydro pump storages to store excess power, produced with solar and wind energy.

\section{Reduction of fossil energy demand and $\mathrm{CO}_{2}$ emissions}

A switch of energy carriers and the reduction of consumption will be indispensable for achieving the major objective of reduction and change of the energy demand.

Figure 5 presents a scenario which should allow to reach a stable concentration of $450 \mathrm{ppm} \mathrm{CO}_{2}$ in the atmosphere (450 ppm case) by 2030 and to reduce the overall energyrelated $\mathrm{CO}_{2}$ emissions (28 Gigatonnes $\mathrm{CO}_{2}$ in 2010) until 2050 by $50 \%$ (14 Gigatonnes $\mathrm{CO}_{2}$ ). The main technical factors to reach this goal are increased efficiency (in total $60 \%$ ), renewables $(17 \%)$ and carbon capture and storage (19\%). The right side of fig. 5 shows that the most important countries where $\mathrm{CO}_{2}$ saving should be performed are China, India and USA. However, both the increase of efficiency and the reduction of emissions is a huge challenge. Actually it is unclear how the goals might be achieved. 


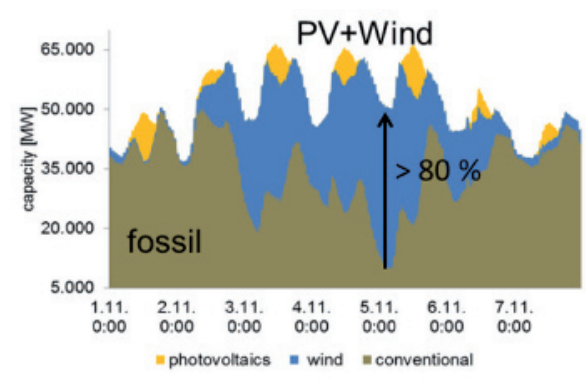

Installed 2020

Wind $46 \mathrm{GW}$

PV $50 \mathrm{GW}$

Demand $100 \mathrm{GW}$

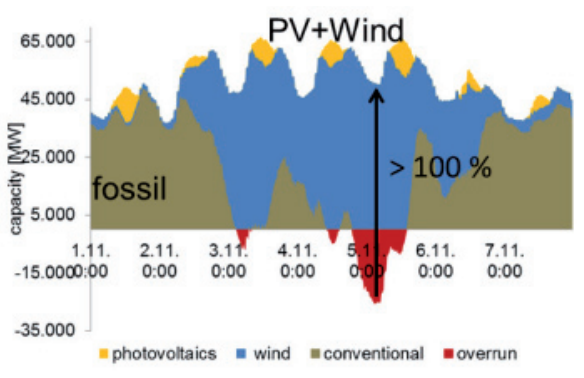

Installed 2025-2030

Wind $75 \mathrm{GW}$

PV $50 \mathrm{GW}$

Demand $120 \mathrm{GW}$

Fig. 6. - power production with fossil(base load), wind and PV. Left:case, if $80 \%$ of power demand is covered by wind and PV. Right: case, if wind and PV covers $>100 \%$ of power demand. Databases [5].

\section{Energy costs}

The production costs of power based on renewables range from 5 to $37 €$-cents $/ \mathrm{kWh}_{\mathrm{el}}[4]$ which is higher than the costs for fossil-based power. Nevertheless, the cost of electricity for end-users ranges between 17 and $25 €$-cents $/ \mathrm{kWh}_{\mathrm{el}}$. Depending on boundary conditions, the cost of power produced with water, biomass, wind and photovoltaic might range at this level. Although we do not want to deepen this aspect at the moment, it should be mentioned that the self-production of power based on renewables might turn out to be attractive for private and industrial consumers and might lead to reduction of power costs even without receiving any governmental aid.

\section{Influence of renewables on conventional power production}

Considering financial governmental aid and regulation for $\mathrm{CO}_{2}$, renewables are as well of interest for power authorities. The increased power production by wind and solar energy influences the operation of conventional power plants which becomes obvious in Germany today. The peak demand in Germany amounts to $100 \mathrm{GW}_{\mathrm{el}}$. In 2011, the installed wind power ranged at $30 \mathrm{GW}_{\mathrm{el}}$ and the installed PV power $20 \mathrm{GW}_{\mathrm{el}}$.

By 2020, almost $100 \mathrm{MW}$ of wind and solar power might be installed in Germany, rising to approximately $120 \mathrm{GW}$ in 2025 . However, synchrony effects will limit the available power. Figure 6 shows the influence on fossil power stations, if $80 \%$ (left) of the load and $>100 \%$ (right) of the load are covered by wind and PV.

As a consequence, fossil power stations will have to be operated in part load operation mode; the fast change of wind and solar power in the range of several (3-7) GW/hour and $>10 \mathrm{GW}$ per day will have to be absorbed by fossil power stations based on coal, natural gas, nuclear or hydro pump storage or other storages. Evidently, the storage of renewable power will be an important factor in the future. As shown on the right-hand 


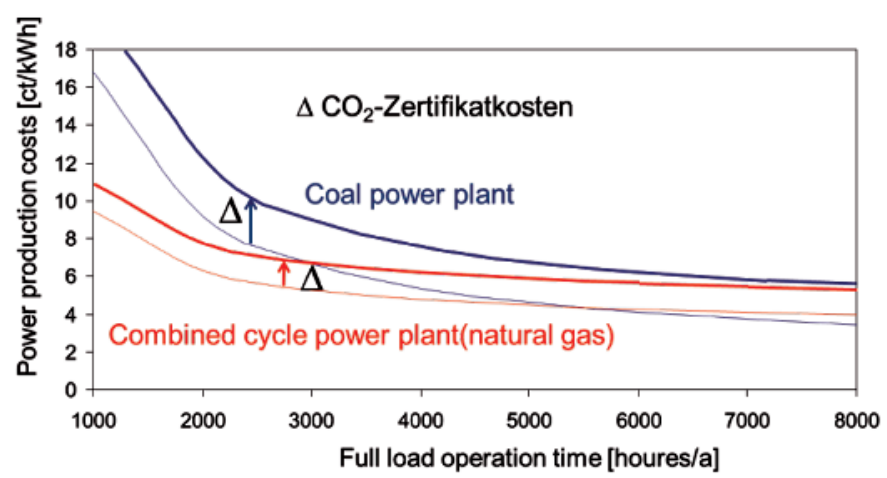

Fig. 7. - The increase of the costs of power production with a coal power plant and a gas fired combined cycle [6].

side of fig. 6 , excess power will be available in the near future, which could be stored and used later on.

The first very important effect is that the full load operation time over the year of coal power stations and natural gas power plants (e.g. combined cycles) will decrease. Due to this fact and the additional costs for $\mathrm{CO}_{2}$ certificates for the operation of fossil power units, the cost for base load power will increase from 4-8 cent to 8-11 cent (fig. 7).

However, most of the existing plants in Germany are older than 20 years and have already been amortized. Thus, investment costs are not an important cost factor for plants already in operation. However, within a period of 20 years, old plants in the range of 20-40 GW will have to be replaced in Germany, $200 \mathrm{GW}$ in the European Union and $2000 \mathrm{GW}$ worldwide (data in fig. 2). The realization of these plants will require some 5-15 years depending on the local regulations and necessary procedures to obtain the permissions for erection and operation.

As a result at the time being, at least in Germany, investments into new fossil power stations are not available, the reasons therefore being the decrease in profit ratio, unforeseeable risks in fuel costs and increasing renewable power sources.

This shows that the realization and operation of coal power stations and gas fired combined power stations is highly influenced by the implementation of renewable power technologies. Solutions to solve these problems are under discussion but not available now. New compensation models for power plants in base load operation mode are one possible solution to overcome the lack of investments. Nevertheless, the production costs of power will increase in the future.

\section{2. - Energy technology}

Among the key factors for the operation of power stations are the $\mathrm{CO}_{2}$ emissions and the availability of storage capacities. The reduction of $\mathrm{CO}_{2}$ can be achieved by using renewables (e.g. co-combustion of biomass) or by separation of $\mathrm{CO}_{2}$ and its use or storage in unmineable coal beds, deep saline aquifers, depleted oil or gas reservoirs or in the cold deep sea. 


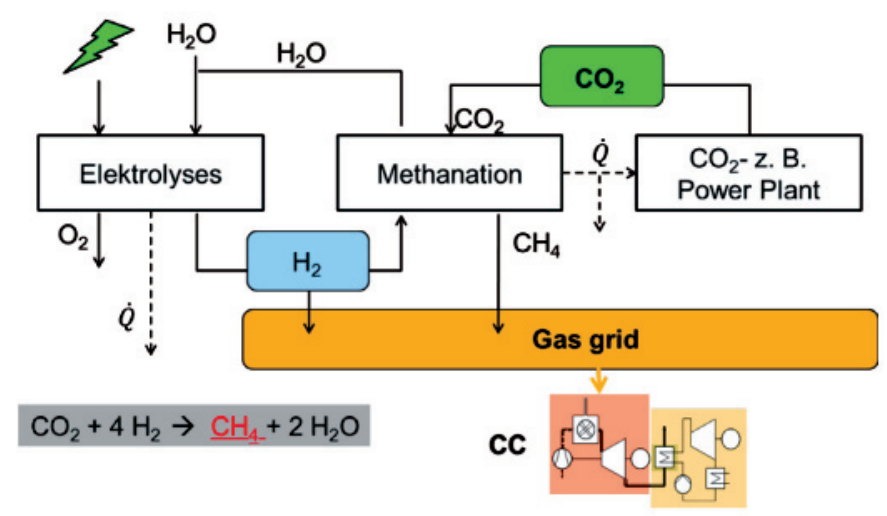

Fig. 8. - Methanation of $\mathrm{CO}_{2}$ with hydrogen.

\section{Storage technologies for power production}

In Germany, the available storage capacity for power with pumped hydro storage (PHS, efficiency 78-85\%) amounts to 7 GW for 7 hours. Norway, Sweden, Austria and Switzerland can provide 38-55 GW. However, the development potential for this type of storage is limited [7-9].

The storage demand in Germany could rise to $80 \mathrm{GW}$ in the future, even though the potential for compressed air storages (CAES) is limited and the use of pure hydrogen is limited by missing infrastructure and high losses due to the diffusion of hydrogen. A possible solution might be the production of methane from $\mathrm{CO}_{2}$ coming from a power station and hydrogen produced with renewable excess power. With it a substitute of natural gas is produced (SNG). The exothermal chemical reaction is known as SabatierReaction and called "methanation".

The reaction takes place at approximately $300^{\circ} \mathrm{C}$ with Ni-catalysts (fig. 8). Important research has to be performed for the electrolysis at full scale of several MW. The resulting product, $\mathrm{CH}_{4}$, can lead to the natural gas grid and can be stored in natural gas storages, the infrastructure therefore being available. Germany alone disposes of $200 \mathrm{TWh}$ of natural gas storage capacity. Methane can be used for power production with high efficient combined cycles (efficiency $60 \%$ ). The overall efficiency from power (renewable) to power from methane will amount to $23-39 \%$, even without making use of the waste heat (exothermal reaction). If the waste heat is also used, the efficiency can rise to $32-$ $69 \%$. However, the process will be economically acceptable only by making use of waste heat and a very high overall efficiency. Otherwise, the cost of power will range from $30-55 €$-cent $/ \mathrm{kWh}_{\mathrm{el}}[10-13]$.

\section{$\mathrm{CO}_{2}$ sequestration}

Figure 9 shows a schematic diagram of the main $\mathrm{CO}_{2}$ capture processes. All of them require steps for separation of $\mathrm{CO}_{2}, \mathrm{H}_{2} \mathrm{O}$ or $\mathrm{H}_{2}$ from the flue gas or synthesis gas. 


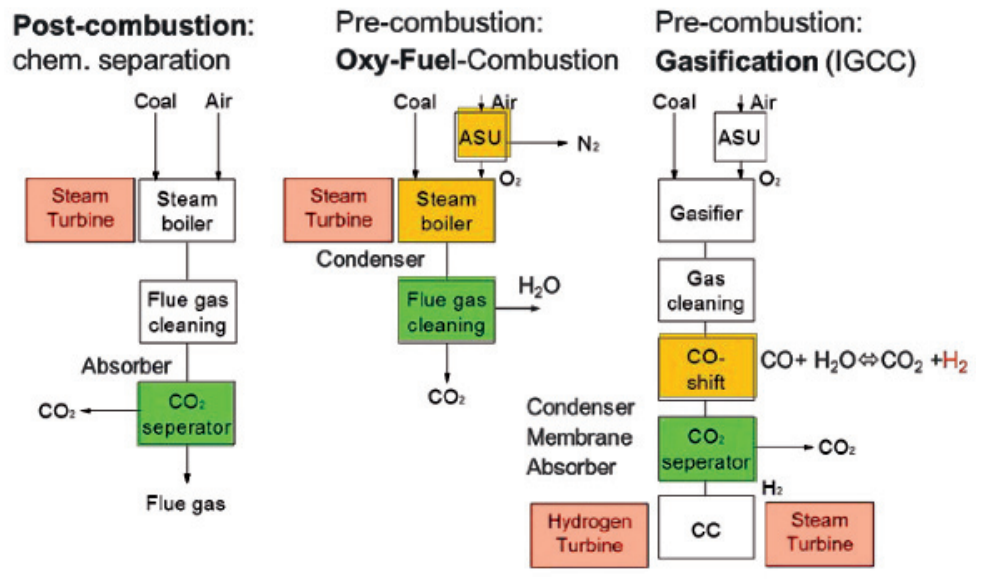

Fig. 9. $-\mathrm{CO}_{2}$ sequestration technologies [14].

Separation can be accomplished either by means of physical or chemical solvents, hightemperature membranes, solid sorbents or by cryogenic separation. The type of specific capture technology chosen depends on the process conditions for operation.

Typically, post-combustion technology uses chemical solvents (e.g. amine scrubbers)for the absorption to remove the carbon dioxide from the flue gas. The combustion takes place with atmospheric air.

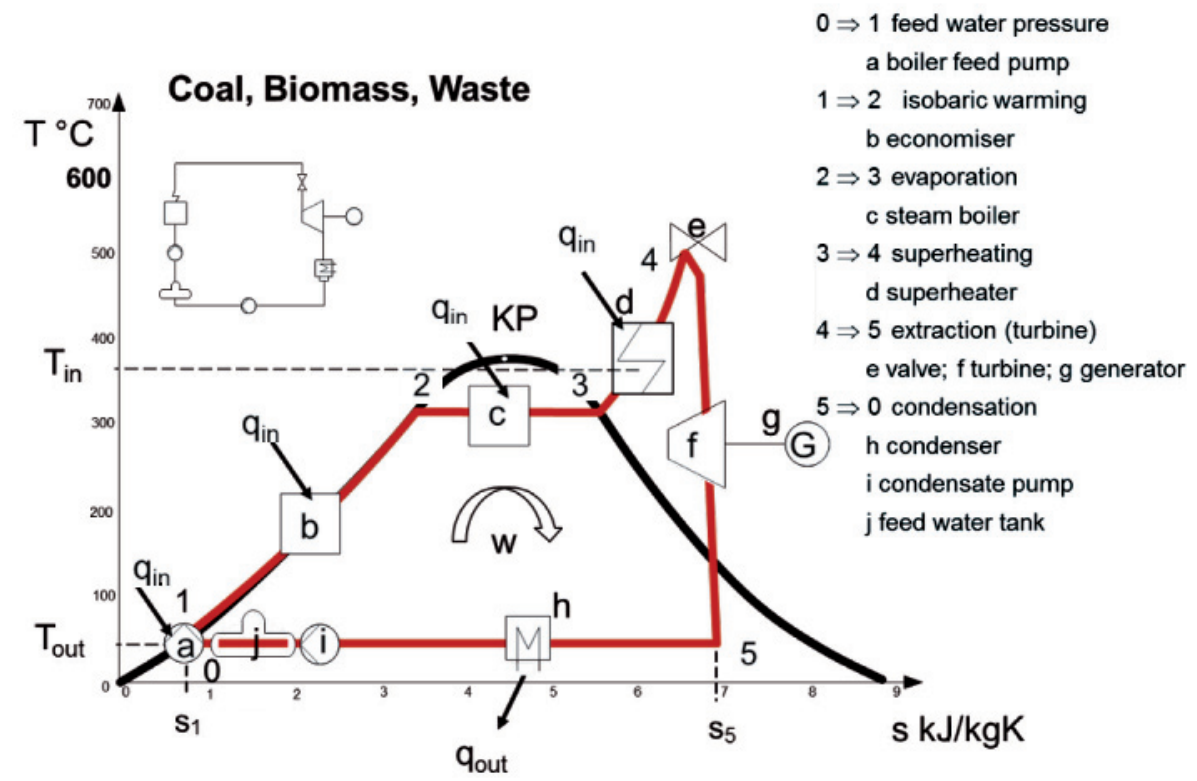

Fig. 10. - Principles of the Clausius-Rankine cycle. 


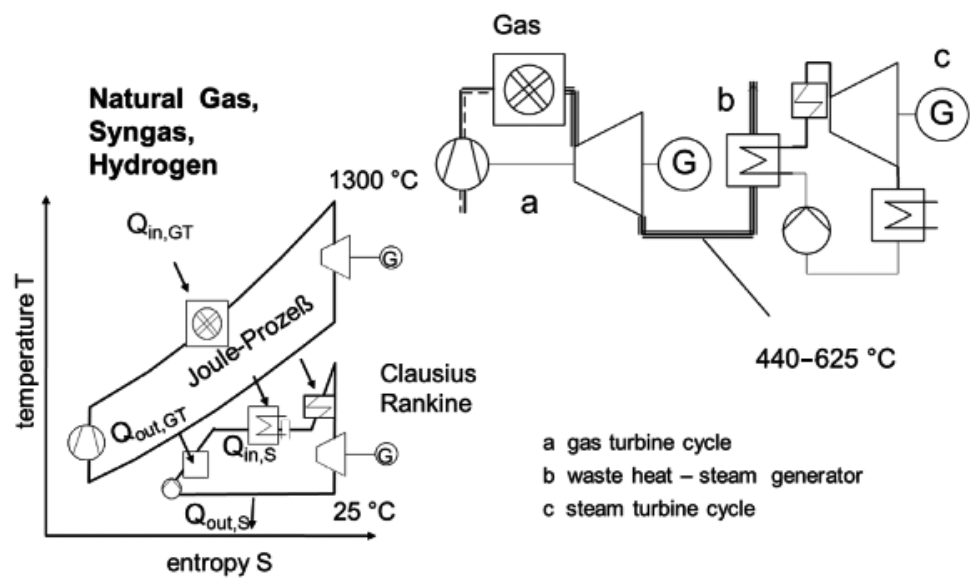

Fig. 11. - Principles of the combined cycle.

The pure oxygen required for pre-combustion is produced by means of an air separation unit (ASU), cryogenic distillation air separation being the standard technology. An alternative to the ASU would be pressure swing adsorption. Pre-combustion can be used for combustion (oxy-fuel-combustion) or for gasification (IGCC). If combustion is used, the flue gas contains mainly $\mathrm{H}_{2} \mathrm{O}$ (as steam) and $\mathrm{CO}_{2}$. The steam can be condensed and separated by cooling down the flue gas, $\mathrm{CO}_{2}$ will remain.

In gasification processes, the pressurized synthesis gas mainly contains $\mathrm{CO}, \mathrm{H}_{2} \mathrm{O}$, $\mathrm{H}_{2}$ and $\mathrm{CO}_{2}$. For the sequestration of $\mathrm{CO}_{2}$ solid sorbents (e.g. CaO), physical liquid solvents (e.g. seloxol) or high-temperature membrane technologies - still being under development - could be used.

For post- and oxy-fuel-combustion cycles, a Clausius-Rankine-Cycle, i.e. a steam turbine cycle according to fig. 10, is used for energy conversion.

For gasification process, a combined cycle (CC) according to fig. 11 -using a combination of a Joule cycle (gas turbine) and a Clausius-Rankine cycle (steam turbine) - is integrated. Hydrogen-rich gas is available for the gas turbine which has to be taken into account for design of the gas turbine.

Figure 12 shows the process of a modern Integrated Gasification with Combined Cycle (IGCC). Pulverized coal is gasified in an entrained flow gasifier in a scale of several $100 \mathrm{MW}$ fuel. IGCCs achieve the highest efficiency if solid fuels are used with the electrical efficiency being in the range of $52 \%$ without $\mathrm{CO}_{2}$ sequestration. If a $\mathrm{CO}_{2}$ sequestration is included, the electrical efficiency will be reduced to $42 \%$.

The different technologies permit capturing $80-95 \%$ of the carbon dioxide produced in coal-fired power plants. Higher capture efficiencies are possible, however, they require considerably larger separation devices which are more energy-intensive and cost-intensive. Capture and compression would require approximately 10-40\% more energy than an equivalent plant without capture, depending on the type of system. 


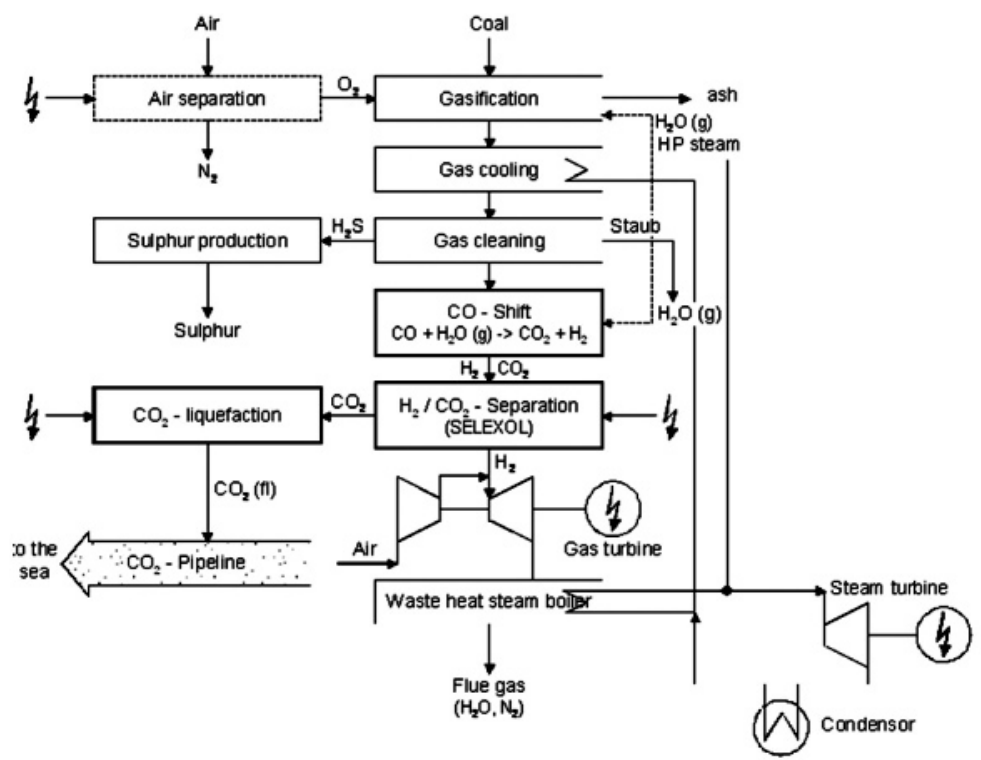

Fig. 12. - Integrated-Gasification Combined-Cycle (IGCC) power plant with $\mathrm{CO}_{2}$ separation (pre-combustion) [14].

Figure 13 shows the effect of $\mathrm{CO}_{2}$ sequestration for lignite. The efficiency decreases by $20 \%$, the specific investment costs will increase by $50 \%$ and thus the production costs for power will increase as well.

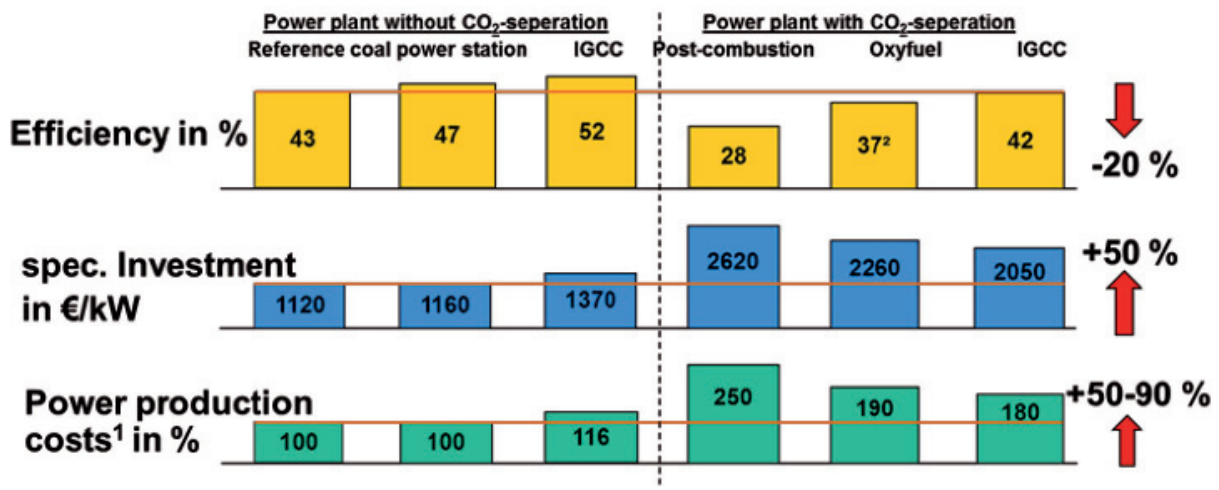

${ }^{1}$ including $\mathrm{CO}_{2}$-compression, liquefaction and $300 \mathrm{~km}$ transport 2including fuel drying $=>+4 \%$-points advantage

Fig. 13. - Effects of $\mathrm{CO}_{2}$ sequestration if brown coal (lignite) is used [14]. 


\section{REFERENCES}

[1] World Energy Outlook 2009, Internationale Energie Agentur, available at: http://www . iea.org/textbase/nppdf/free/2009/WE02009.pdf, 2010.

[2] Gaderer M. and Spliethoff H., Thermische Nutzung von Biomasse und Reststoffen in Deutschland, Thermal Use of Biomass and Residual Materials in Germany, Chemie Ingenieur Technik, Special Issue: Energie, Vol. 83, N. 11 (2011) pp. 1897-1911.

[3] International Energy Agency (IEA): Energy Technology Perspectives 2010, Executive Summary, Scenarios and Strategies 2050, available at: http://www.iea.org/techno/etp/ index.asp, 2010.

[4] Kost C. and Schlegl Th. et al., (2012) Studie Stromgestehungskosten Erneuerbare Energien, 2012, Fraunhofer Institut für Solare Energiesystem ISE, available at: http://www.ise.fraunhofer.de/de/veroeffentlichungen/veroeffentlichungen-pdfdateien/studien-und-konzeptpapiere/studie-stromgestehungskosten-erneuerbareenergien.pdf.

[5] European Energy Exchange AG (EEX), available at: http://www.transparency.eex.com/ de, 2012.

[6] Spliethoff H., Wauschkuhn A. and Schuhbauer C., Anforderungen an zukünftige Kraftwerke, Future Power Plant Requirements, Chemie Ingenieur Technik, Special Issue: Energie, Vol. 83, N. 11 (2011) pp. 1792-1804.

[7] Wiedemann K., Einmal Fjord und zurück. Neue Energie, 07 (2010) 24.

[8] ETG-Task Force Energiespeicherung et al.., Energiespeicher für die Energiewende, 2012, VDE Studie, Erhältlich beim Verband der Elektrotechnik.

[9] Sachverständigenrat für Umweltfragen, 100\% erneuerbare Stromversorgung bis 2050: klimaverträglich, sicher, bezahlbar, SRU/Stellungnahme Nr. 15-2010, ISSN 1612-2968, 2010.

[10] DLR (Deutsches Zentrum für Luft- und Raumfahrt): Möglichkeiten und Grenzen der Integration verschiedener regenerativer Energiequellen zu einer $100 \%$ regenerativen Stromversorgung der Bundesrepublik Deutschland bis zum Jahr 2050. Endbericht, Stuttgart, DLR, 2010.

[11] Crotogino F., Einsatz von Druckluftspeicher-Gasturbinen-Kraftwerken beim Ausgleich fluktuierender Windenergie-Produktion mit aktuellem Strombedarf. Vortrag, Tagung "Fortschrittliche Energiewandlung und -anwendung der VDI-Gesellschaft Energietechnik", Stuttgart, 11. und 12. 03. 2003.

[12] Smolinka T., Günther M. and Garche J., Stand und Entwicklungspotential der Wasserstoffelektrolyse zur Herstellung von Wasserstoff aus regenerativen Energien (NowStudie), Fraunhofer ISE, FCBAT, 2011, available at: http://www.now-gmbh.de/ fileadmin/user_upload/RE-Mediathek/RE_Publikationen_NOW/NOW-StudieWasserelektrolyse-2011.pdf.

[13] Würtenberger U., Linde Clean Energy Power to Gas Technologie, Vortrag Arbeitsgruppe Power to Gas des Bayerischen Wirtschaftsministeriums, 19.06.2012.

[14] Spliethoff H., Power generation from Solid Fuels (Springer) 2010, ISBN 978-3-64202855-7. 